\title{
Whole-Life Career Management: A Counseling Intervention Framework
}

\author{
Andreas Hirschi, Institute of Psychology, University of Bern, Switzerland
}

This is an unedited manuscript accepted for publication in the Career Development Quarterly. Please note that the published version might undergo minor additional editing in style and content.

Complete reference: Hirschi, A. (in press). Whole-Life Career Management: A Counseling Intervention Framework. Career Development Quarterly

Correspondence concerning this article should be addressed to:

Andreas Hirschi, Institute of Psychology, University of Bern, Fabrikstrasse 8, CH-3012 Bern, Switzerland (e-mail: andreas.hirschi@psy.unibe.ch)

\begin{abstract}
It is widely recognized that career management and counseling require a consideration of work and nonwork roles. I present a career counseling intervention framework to help clients self-direct their careers and attain work-nonwork balance. Based on an action-regulation approach, the framework consists of four phases: (1) Clarifying goals across work and nonwork roles; (2) mapping resources and barriers related to goal attainment; (3) developing action strategies for goal attainment; and (4) monitoring and adapting goal pursuit across work and nonwork goals. I outline the theoretical foundations of this framework, provide a case study on how the framework can be applied in individual counseling, and give examples of specific intervention contents. The framework provides a foundation for career counseling practice to assist clients in managing their careers under considerations of nonwork roles. Research can use the framework to gain a better understanding of career self-management from a whole-life perspective.
\end{abstract}

Keywords: work-nonwork; career counseling; work-life balance; work-family; action regulation 


\section{Whole-Life Career Management: A Counseling Intervention Framework}

At least since Super introduced his seminal life-span, life-space approach (Super, 1957, 1990), the importance of understanding career development as an active, lifelong process at the intersection of various life roles has shaped the field of career development and counseling. Due to demographic and technological changes and shifting gender norms, there is today an increased need to consider nonwork roles when managing a career (Greenhaus \& Kossek, 2014). Career counselors have also been encouraged to more prominently consider with clients the work-family interface, for example, by clarifying the salience of different life roles, increasing social support in work and family, and helping to promote a sense of competence in work and family (Slan-Jerusalim \& Chen, 2009; Whiston, Campbell, \& Maffini, 2012; Whiston \& Cinamon, 2015). As a consequence, a contemporary approach to career counseling should help clients in managing their careers from a whole-life perspective, which can be defined as a consideration of one's career in the context of one's entire life across work and nonwork roles (DiRenzo, Greenhaus, \& Weer, 2015; Litano \& Major, 2016). Given the importance of this topic, there is a need to derive specific models of how people can successfully integrate work and other life roles, including frameworks that can be used in career intervention practice (Greenhaus \& Kossek, 2014). To address these issues, the current paper aims to present a career counseling intervention framework that can be used to assist individuals in managing their careers under consideration of nonwork roles.

\section{Intervention Approaches to Work-Life Integration}

Several intervention approaches exist that aim to help individuals attain better worklife balance, defined as being actively engaged in and having a sense of competence and satisfaction across life roles in accordance with personal values (Wayne, Butts, Casper, \& Allen, 2017). Organizational interventions mostly focus on contextual issues or very specific personal resources. For example, such interventions aim to promote personal resources, such as mindfulness (Kiburz, Allen, \& French, 2017), or change the work context in terms of increasing job resources and reducing job demands, such as by increasing family-supportive supervisor behaviors, enhancing employee schedule control, or implementing a focus on work results instead of work hours (Hammer, Kossek, Anger, Bodner, \& Zimmerman, 2011; Kossek, Hammer, Kelly, \& Moen, 2014).

Counseling approaches that assist clients to reflect on work and nonwork roles include Career Construction (Savickas, 2013) and Life Design (Savickas, 2012) that advocate a holistic view on career development. These approaches help clients in selfconstruction in all important life roles by becoming aware of the salience of different life roles, defining priorities, identifying supports and cultivating resources, and engaging in activities in different life roles. Also the integrative life planning approach (Hansen, 2001, 2011) takes a 
holistic view on career counseling by seeing work in relation to other life roles and helping clients to negotiate roles and relationships. Moreover, there are group interventions that aim to help young adults manage the work-family interface by exploring the meaning attributed to work and family roles, providing information on role relations, and building skills for role management (Cinamon, 2014).

\section{Need for a More Specific Intervention Framework}

Several contemporary career counseling frameworks thus broadly acknowledge the importance of taking a whole-life approach and frequently include a focus on work and nonwork goals and life roles. Existing frameworks are typically not very specific, however, regarding how clients can be assisted in managing their career while considering nonwork roles. Moreover, they mostly focus more narrowly on reflections on work and nonwork role relations, negotiating roles and relationships, or managing role boundaries. While these approaches are all meaningful, they do not sufficiently address how individuals can be assisted in the successful attainment of goals across work and nonwork life domains. This is a potentially important omission because, according to the action regulation model of workfamily balance (Hirschi, Shockley, \& Zacher, 2019), individuals can attain more work-life balance by actively managing work and nonwork goals through the targeted use of various action regulation strategies. What is lacking in the literature are more specific intervention frameworks that clearly outline how individuals can be assisted in achieving more balance by developing and implementing better action strategies in the active pursuit of personally valued goals across life roles.

To address this issue, I herein propose a framework based on the model by Hirschi et al. (2019) that offers a theoretical account of how people can attain work-nonwork balance through the application of various action strategies and under consideration of demands, resources, and barriers in work and nonwork roles. In contrast to other theoretical frameworks, their model focuses on individual actions to achieve balance and sees individuals as active agents that aim to attain centrally valued goals across life roles. The current paper contributes to the career counseling intervention literature by deriving specific intervention steps and components based on this general framework. The presented intervention framework adds to existing organizational and career counseling approaches in that it goes beyond promoting specific personal or contextual resources, or helping individuals more specifically in self-construction or role-boundary management. Instead, it more broadly focuses on helping individuals with action regulation in the active pursuit of work and nonwork goals.

\section{Whole-Life Career Management: A Counseling Framework}

The framework I propose here is built on an action regulation approach. The action regulation approach sees individuals as exerting agency by developing and selecting goals, 
mapping the environment for opportunities and constraints, developing action plans and engaging in goal-directed behaviors, monitoring the action regulation process, and processing feedback and adapting accordingly (Frese \& Zapf, 1994; Zacher \& Frese, 2018). According to the model by Hirschi et al. (2019), people use various action strategies to attain centrally valued aims (i.e., goals) across work and nonwork roles that contribute to a sense of balance. Different action strategies are used depending on available resources, existing barriers, and the time available to attain work and family goals. These strategies include allocating and activating resources, changing resources and barriers, sequencing work and family goals, or revising and developing new work and family goals. Balance then emerges from the sense of competence and satisfaction in different life roles that results from goal engagement, goal progress, and goal attainment across roles (Hirschi et al., 2019).

Based on these theoretical considerations, the proposed framework is built on four key components or phases as seen in Figure 1. In these four phases counselors assist clients in (a) clarifying work and nonwork goals and identifying facilitating and inhibitory linkages between the two; (b) identifying personal as well as environmental resources and barriers related to work and nonwork goal attainment; (c) developing action plans to jointly attain work and nonwork goals; and (d) regularly reviewing actions, goal progress, role expectations, resources, and barriers and in adapting goals, action plans, and behaviors accordingly.

Table 1 gives an overview of core aims and possible content of each phase. The four phases are presented in a logical sequence in which interventions should proceed. However, in practice, there can be feedback loops between stages such that insights gained in one phase can be used to better address the aims of a previous phase. Hence, it is possible to use the phases described below in a more flexible order in practice, for example, by returning to clarifying goals after the development of action strategies has shown that existing goals are unattainable or ill-defined.

\section{Stage 1: Clarifying Work and Nonwork Goals and Their Linkages}

Goal clarification across life roles. In the first stage, counselors assist clients in developing and setting goals in work and nonwork life roles. They moreover help client attain a clearer understanding of how work and nonwork goals are related, including the potentially positive and negative effects across goals in different life domains. Goals are at the basis of self-directed behaviors (Zacher \& Frese, 2018) and direct attention and effort towards goalrelevant activities, energize people to exert effort and persistence in goal pursuit, and support the discovery and use of goal-relevant knowledge and strategies (Locke \& Latham, 2002). Moreover, goals can provide a sense of purpose and meaning (Latham \& Locke, 2006) and making progress towards personally meaningful goals is an important source of psychological well-being (Lent \& Brown, 2006) because it creates a sense of 
accomplishment and personal effectiveness, which are basic psychological needs (Latham \& Locke, 2006).

Goals are hierarchically structured (Unsworth, Yeo, \& Beck, 2014) and range from higher-level goals such as values (e.g., importance of being a good parent; importance of recognition for one's work) and identities (e.g., seeing oneself as a caring parent; seeing oneself as a high-performing employee), to intermediate-level project goals (e.g., having children in the next few years; getting a promotion), and more specific task goals (e.g., helping one's child with homework this evening; finishing a work report next week). Higherlevel goals are by definition more abstract and longer-term while lower-level goals are more specific and shorter-term (Unsworth et al., 2014).

In this stage of the intervention, clients should be encouraged to identify higher- to medium-level goals in terms of the values, identities, and projects they aspire to. These goals are then linked with lower-level task goals in Stage 3 of the process, where the specific actions necessary to achieve these goals are identified. Focusing on higher-level goals first is important because higher-order goals help individuals linking their actions with higherorder consequences and thus seeing the larger meaning of their actions. Vallacher and Wegner (1987) call this action identification and research suggests that people who perceive their actions in more general terms experience more positive affect in goal pursuit (Freitas, Clark, Kim, \& Levy, 2009). This can be explained in the way that linking lower-level goals and actions to general higher-level goals creates a sense of self-concordance in that actions are perceived as more personally meaningful due to their connections to higher-level goals (Unsworth et al., 2014). Moreover, action identification can enhance a sense of goal concordance in that different goals can be understood as facilitating the same higher-order goal, thus reducing the sense of potential conflict between multiple goals (Clark \& Freitas, 2013). Hence, at this stage, clients should be encouraged to think about and identify the states or objects that they centrally value in their work and nonwork lives. Moreover, clients should be assisted in crystalizing their identities in work and nonwork life roles in terms of what kind of person they aspire to be across life domains. These higher-level goals can then inform a reflection about more specific project goals in work and major nonwork roles.

Importantly, this stage explicitly addresses the point that people are simultaneously engaged in multiple life roles. People vary in the specific life roles that they inhabit as well as in the subjective importance they attribute to these roles (Greer \& Egan, 2012). An important aspect of this intervention stage is thus to clarify which central life roles a client inhabits and what level of importance is attached to each. This approach is based on the notion that people can have multiple identities and that these identities can vary in number and importance (Ramarajan, 2014). Clarifying these identities and their respective values and 
aims is thus a critical part in identifying and developing higher-level goals in work and nonwork roles.

However, goals do not just emerge out of individual values and identities. Rather, goals, including values and identities, are strongly influenced by contextual factors (Ramarajan, 2014; Unsworth et al., 2014). According to the action-regulation perspective on work-family balance (Hirschi et al., 2019), people translate environmental demands into personal work and nonwork goals. In the work-family literature, this notion is represented by the importance of role senders that shape the work-nonwork interface with their expectations for work and nonwork behaviors and desired outcomes (Edwards \& Rothbard, 2000). Clients should thus also be encouraged to discuss role expectations with important role senders (e.g., spouse, supervisor, team members) and to consider these expectations when developing goals.

Consideration of goal linkages across life roles. To promote a whole-life perspective on career management, counselors should encourage clients to consider how their work goals relate to their nonwork goals, and vice versa. In a multiple goal system, different goals show various degrees of facilitating and inhibitory connections (Kruglanski et al., 2002). When pursuing multiple goals, it is thus important to understand how the pursuit of one goal can positively or negatively affect the attainment of other goals. Work and nonwork life domains can be in conflict but can also enrich each other (Allen, Cho, \& Meier, 2014). These mutual effects can represent a positive or negative spillover of affect, values, skills, or behaviors from one role to the other, a compensation of different roles for aspects that are lacking in a given role, or result from resource drain when fulfilling demands in a given role (Edwards \& Rothbard, 2000).

An important component of these mutual effects between work and nonwork roles is that different roles have different boundaries in terms of their flexibility and permeability (Allen et al., 2014). Flexibility refers to the extent to which roles can be enacted in a variety of settings and different times (e.g., flexibility in working early in the morning or late at night). Permeability refers to the extent to which a person physically located in one role can be psychologically or behaviorally engaged in another other role (e.g., working while at home). Research suggest that not only do roles differ in their flexibility and permeability, but individuals also have different preferences to which extent they aspire to segment or integrate life roles (Allen et al., 2014). To clarify how work and nonwork goals relate to each other, clients should thus be assisted in clarifying the nature of the boundaries that separate different life roles physically and psychologically, what personal preferences they have regarding these boundaries, and how this affects their ability to jointly attain work and nonwork goals (Kossek, Ruderman, Braddy, \& Hannum, 2012). 


\section{Stage 2: Mapping Resources and Barriers Related to Work and Nonwork Goals}

In the second stage counselors assist clients to map available supports and barriers as well as opportunities and constraints for goal pursuit and attainment (Zacher \& Frese, 2018). In accordance with the action-regulation model of work-family balance (Hirschi et al., 2019), I define resources as everything that helps a person attain their work and family goals. Conversely, barriers are everything that inhibits work and nonwork goal pursuit and attainment.

Resources are essential in meeting role demands and can also be transferred from one role to another to facilitate performance across different roles (ten Brummelhuis \& Bakker, 2012). Resources can exist at the personal as well as various contextual levels and be more volatile (e.g., positive mood; available support from a supervisor or spouse) or more structural (e.g., professional expertise; family supportive organizational policies; ten Brummelhuis \& Bakker, 2012). Moreover, macro resources (e.g., culture, public policies) and personal key resources (e.g., self-esteem, social power) can facilitate or inhibit the ability to meet demands and utilize other resources to achieve desired outcomes (ten Brummelhuis \& Bakker, 2012). Barriers on the personal level can include anxiety (more transient) or depressed mood (more structural) while contextual barriers could be the destructive behavior of a spouse (more transient) or cultural discrimination against working mothers (more structural).

According to Social Cognitive Career Theory, environmental supports and barriers effect a person's self-efficacy for specific career choices and goals and can also directly affect goals, actions, and outcomes of career development (Lent \& Brown, 2013; Lent, Brown, \& Hackett, 2000). Being aware of available support and barriers, including knowledge of how to utilize resources and address barriers is also a key component of career preparedness and the ability deal with expected and unexpected career challenges (Lent, 2013). Moreover, research on resilience and psychological capital interventions showed that a key component of effective programs is to enhance people's ability to build assets and anticipate adverse events and how to deal with them (Luthans, Avey, Avolio, Norman, \& Combs, 2006; Vanhove, Herian, Perez, Harms, \& Lester, 2016). A key component of the intervention at this stage is thus to help clients identify resources at different levels-from the individual to the macro-level-that can facilitate goal pursuit and attainment across work and nonwork goals. In addition, clients should be encouraged to think about personal and contextual barriers that make it difficult to attain work and nonwork goals.

To support a whole-life perspective on career management, counselors should specifically encourage clients to identify boundary-spanning resources and barriers, that is, resources and barriers that simultaneously facilitate or inhibit goal attainment across multiple roles (Hirschi et al., 2019). For example, high self-esteem can help to attain work and 
nonwork goals because it can increase confidence to successfully manage multiple life demands, while an organizational culture that focuses on face time can inhibit the attainment of work as well as nonwork goals because it can make spending time at home more difficult while also reducing chances of promotion when not working long hours.

\section{Stage 3: Developing Action Strategies to Jointly Attain Work and Nonwork Goals}

In the third stage, counselors assist clients to develop specific action strategies that help to attain personal goals, under consideration of resources and barriers (Zacher \& Frese, 2018). Here, clients are encouraged to develop more specific and short-term goals and identify specific actions that help to achieve the higher-order goals identified in Stage 1 of the intervention. Clients should be assisted in breaking down higher-level, more abstract, and more distal goals into a series of lower-level, more specific, and more proximal sub-goals and actions. One way to achieve this is by asking "what needs to happen first before this goal can be attained" and thereby identifying more and more specific and shorter-term goals (Campbell \& Ungar, 2004). In doing this, the core features of goal multifinality and goal equifinality in multiple goal systems should be considered (Kruglanski et al., 2013; Kruglanski et al., 2002). Multifinality means that specific actions or lower-level goals can lead to the attainment of multiple higher-level goals. For example, switching careers can facilitate the goal of career progression but also the goal of getting more flexibility in work hours to meet family demands. Goal equifinality means that different actions or lower-level goals can lead to the same higher-level goal. For example, working long hours and building social support can both contribute to the goal of getting a promotion.

Based on these ideas, clients should be encouraged to identify actions and sub-goals that facilitate goal attainment in work and nonwork roles simultaneously. For example, a client may identify the action of negotiating more flexibility in work hours with her supervisor to better attain the goal of caring for her child's needs as well as for increasing efficiency at work. Also, clients can be helped in identifying alternative ways to reach certain goals and that help avoid conflict between work and nonwork goals. For example, instead of working long hours to attain a promotion, the alternative means of soliciting support from work colleagues could be used. Identifying alternative means to achieve goals is also a way how clients can circumvent existing barriers.

A consideration of goal multifinality and equifinality moreover helps clients to consider how actions affect goal attainment across work and nonwork roles. As such, better goal alignment can be achieved, and clients can be assisted in choosing action strategies that optimally consider the resources and barriers related to work and nonwork goals. According to the action-regulation model of work-family balance, counselors can help individuals in developing four general action strategies to jointly attain work and nonwork goals (Hirschi et al., 2019). The first strategy (allocating) consists of identifying available resources and 
developing strategies of how these resources can best be deployed to meet goals across life roles. In implementing this strategy, counselors can help clients in identifying the actions that optimally use available resources and circumvent existing barriers to jointly attain work and nonwork goals. The second strategy (changing) is to identify ways how additional resources can be generated or how existing barriers can be reduced. Counselors can help clients in developing ways how they can increase personal and structural resources and in developing strategies of how to address existing barriers. This can include helping clients to negotiate with family members, work colleagues, or supervisors to augment resources (e.g., social support, work hour flexibility) or reduce barriers (e.g., face time culture). The third strategy (sequencing) applies when resources and barriers cannot be sufficiently changed to permit joint goal attainment across work and nonwork roles, but some goals have temporal flexibility in when they can be attained. In this instance, clients can be assisted in identifying goals that can be postponed temporality to first focus available resources on other goals. Ideally, the temporarily prioritized goal should later facilitate the attainment of the postponed goal, such as when getting a promotion first can help to attain the goal of caring for children due to increased financial resources and flexibility in work hours. Finally, the fourth strategy (revising) applies if goals in work and nonwork roles cannot be jointly attained with any of the previous strategies. This strategy aims to change or abandon some work or nonwork goals and establish new goals that better fit with the available resources and barriers.

\section{Stage 4: Monitoring Goal Progress and Adapting}

The fourth phase is to monitor goal progress, obtain feedback on how one is doing in relation to attaining goals, and process this feedback to improve goal attainment (Zacher \& Frese, 2018). Such feedback loops are a core feature of self-regulation theories (Lord, Diefendorff, Schmidt, \& Hall, 2010) and empirical research has confirmed that monitoring goal progress is associated with better goal attainment (Harkin et al., 2016). This feedback is not limited to the absolute level of current performance relative to a desired goal but also includes an assessment of the speed (velocity) at which one is making progress towards attaining a goal (Johnson, Chang, \& Lord, 2006).

An important component of monitoring and feedback processing for better goal attainment is to monitor the extent to which behaviors help to attain goals and adjust behaviors and action plans accordingly if goal progress is insufficient or too slow. However, according to an action-regulation perspective, people are not just reacting to observed discrepancies between current performance and aspired goals. Rather, people also actively engage in setting new goals and adapting and managing existing goals and their corresponding behaviors (Zacher \& Frese, 2018). Hence, monitoring also includes assessing role expectations, resources, and barriers related to existing goals and adjusting existing goals or action plans if these factors change considerably. This process is thus essential to 
allow clients to be adaptable and flexible in their career pursuits and to capitalize on unexpected opportunities if they arise (Krumboltz, 2009). Included in this process is the possibility that clients need assistance in disengaging from goals that are no longer feasible. The ability to disengage from unattainable goals and re-engage in new goals is a key component of successful action-regulation across the lifespan (Heckhausen, Wrosch, \& Schulz, 2010; Zacher, Kooij, \& Beier, 2017) and disengagement from unattainable goals combined with reengagement in new goals is related to higher subjective well-being (Wrosch, Scheier, Miller, Schulz, \& Carver, 2003).

A key task in this stage is for counselors to clients in establishing how and when they will monitor if (a) their actions correspond to their plans, (b) their actions result in the desired outcomes, and (c) significant changes occurred in role expectations, resources, or barriers. Based on this monitoring, clients can then be helped in processing this feedback and how to change behaviors, action plans, or goals accordingly. This might entail assisting clients in dealing with the resistance and disappointment that can accompany disengagement from goals and developing new goals that are more attainable. As work and nonwork goals are also developed due to contextual influences, this might also entail helping clients renegotiate role expectations with important role senders.

\section{Case Study}

To illustrate application of the model, the following is an abbreviated description of a hypothetical individual career counseling case based on experiences with different clients. Richard (a pseudonym) was a 42 year old man who worked as a project manager in controlling since he graduated from college. He had a wife who was working as a lawyer, and two children, ages 3 and 6 . He sought career counseling because he has felt a dissatisfaction in his current job due to a lack of professional development for several months and was looking for a new challenge.

\section{Stage 1: Clarifying Work and Nonwork Goals and Their Linkages}

Richard and the counselor agreed that the main goal of counseling was that Richard achieves more clarity about what he can do to address his current job dissatisfaction. Richard stated that besides his work, his family life was also very important to him and he wanted to take his family needs into account when making career plans. Accordingly, Richard and the counselor agreed that a counseling process that takes a whole-life perspective was most suitable to address the counseling aim.

The counselor explained that to attain work-life balance, it is important that Richard be clear about what he wanted to attain across different life roles and how these life roles were linked. The counselor asked Richard to reflect on what was important for him in the work and family role and to name long-term goals that he would like to attain in his professional career as well as in his family life. Richard noted that it was important for him to 
have challenging and interesting work as well as being a caring and involved father and having a loving relationship with his wife. The counselor then asked him to reflect on how these goals were linked with each other: "In what way can these goals help each other? Are there ways that they are in conflict?" To assist in this process, the counselor asked Richard to note his goals on paper and draw lines between goals in different colors to indicate their facilitative or inhibitory linkages, where a green line indicated a facilitative link and a red line a potential conflict. Richard identified a potential goal conflict in that he felt having challenging work sometimes necessitated that he work in the evenings at home which made it hard for him to be engaged with his children and spend quality time with his wife. However, he also saw how his goals facilitate each other, because spending quality time with his children and wife made him feel happy and energized him to be more engaged at work.

\section{Stage 2: Mapping Resources and Barriers Related to Work and Nonwork Goals}

The counselor explained how different types of resources can promote goal attainment and how using resources and action strategies (e.g., backup plans) can help in dealing with barriers to goal attainment. The counselor asked Richard to note in writing personal as well as contextual resources at work as well as in his nonwork life than help him attain the previously mentioned work and family goals. The counselor assisted Richard in this process by providing illustrative examples of different types of resources, such as abilities or motivation as forms of personal resources and social support or organizational programs as contextual resources. By asking open questions, the counselor clarified different resources in various areas that Richard might have. The counselor also assisted Richard in thinking about how some resources might be helpful to attain goals in both the work and family domain.

Richard stated that he had a supportive supervisor and that he was a fast learner at work which would help him when facing new work challenges. Moreover, Richard saw the relationship with his wife as helping him dealing with stress at work. The counselor then asked Richard to reflect on potential barriers that prevented him from attaining his work and family goals, and to think about and write down available resources or action strategies that he might use to address each of these barriers. Richard noted that he often faced very short work deadlines which necessitate extra work and made it hard for him to meet family needs. However, he noted that he had a good relationship with his supervisor which would help in addressing this issue. Moreover, his wife had some flexibility in her work schedule which allowed her to take care of the children when he was too busy with work. However, he also felt that the professional engagement of his wife and his responsibilities as a father imposed some limitations on the work hours and work demands he could take on. Richard noted that speaking with his wife about how they could arrange family responsibilities while both remained professionally engaged might be helpful to address this issue. 


\section{Stage 3: Developing Action Strategies to Jointly Attain Work and Nonwork Goals}

The counselor explained that to attain long-term goals, it is important to break them down into several short-term goals by identifying specific actions that lead to these goals. With the help of the counselor, Richard identified for each previously named goal "what needs to happen before that" and wrote down the sequence of intermediate goals or steps that could lead to each goal. The counselor helped Richard to consider how he could activate existing resources, build additional resources, and use strategies to deal with barriers. To address the barrier of short work deadlines that inhibited his ability to attain his goal of being engaged at home, Richard wrote down that he could capitalize on the resource of having a good relationship with his supervisor and talk with her next Monday on how they could arrange work tasks and deadlines differently. To further capitalize on this existing resource to better attain the goal of having more challenging work, he also wanted to ask her to help him identify development opportunities that might exist in the company. Moreover, he planned to speak with his wife about how they could arrange childcare work if he would take on new challenges at work. Moreover, he wanted to discuss how they could make sure that despite potential changes at work, they maintained dedicated space for quality family and partner time.

\section{Stage 4: Monitoring Goal Progress and Adapting}

In the last phase of the counseling process, the counselor explained that it is important to regularly monitor and if necessary revise actions for goal attainment. Assisted by the counselor, Richard wrote down a specific way how he could check if he was making progress towards his goals, including when and how he could make that check. The counselor also assisted Richard in thinking about "if...then" contingency plans in case goal progress was not as intended. Richard noted that he would check by the end of next week if he had talked to his supervisor about work deadlines and development opportunities and what the outcomes of this talk were. If there would be possibilities to get more challenging tasks or move to more challenging positions in the company, he would also speak with his wife on how they could arrange childcare and family time in light of such potential changes at work. He would moreover check in two months if he was making sufficient progress towards having more challenging work while also being able to stay engaged at home. If there was no sufficient improvement, he would consider looking for a new job.

At the end of counseling, Richard and the counselor reviewed the process and evaluated if the counseling goal has been met. They also agreed that the counselor will check-in by email at Richard's noted check-up time after two months to ask how the implementation of the identified steps was making progress, and if a follow-up appointment was necessary to discuss further steps. 


\section{Practice and Research Implications}

The intervention framework described herein can be used to derive career counseling interventions to assist individuals in attaining centrally valued goals in work and nonwork life domains. As such, the framework addresses the call to include work-nonwork issues in career counseling (Whiston \& Cinamon, 2015) and derive practice applications for whole-life career self-management (Greenhaus \& Kossek, 2014). The framework describes a general process for interventions of different formats, including face-to-face counseling with single clients, workshops, group interventions, or online interventions. The framework could also be useful for work-family interventions more generally, for example in organizational settings.

Interventions based on the framework should moreover be suitable for a wide range of clients who desire to address career development needs from a whole-life perspective, irrespective of their age, gender, or socio-economic status. The framework is versatile enough to allow integrating a range of specific counseling approaches and techniques to achieve the described aims, and to be adapted to specific target groups. For example, narrative and constructionist approaches (e.g., Savickas, 2012) could be used to help clients identify core values and construct meaningful identities across work and nonwork roles. In addition, more traditional self-assessments of values, vocational interests, or vocational preferences (Whiston, 2008) could be used to help clients identify meaningful work goals that can then be related to nonwork goals.

Apart from providing a template for career counseling practice interventions, the framework could also be a useful foundation for future research. For the work-family research domain, the framework can serve as a template to conduct research on the largely neglected importance of intent in managing the work-nonwork interface (Edwards \& Rothbard, 2000). Interventions based on this framework could be used in (quasi)experimental research to examine the causal effects of individual actions in managing the work-nonwork interface, for example in trying to align work and nonwork demands and resources (ten Brummelhuis \& Bakker, 2012).

Because a protean career orientation is characterized by being values-driven, selfdirected, and having a whole-life perspective on career development (Hall, Yip, \& Doiron, 2018), the present framework seems very well suited to systematically enhance such a career orientation. Applying the framework, future studies could address the need to evaluate if a protean career orientation can be changed and to assess causal mechanism based on intervention research (Hall et al., 2018). Moreover, the framework could be useful for research on career self-management from a social-cognitive perspective (Lent \& Brown, 2013). A career intervention based on the herein presented framework could be used as a learning experience to examine how this changes self-efficacy and outcome expectations for 
work-nonwork management, work-nonwork goals, and subsequent career self-management behaviors across work and nonwork domains.

Career management requires a consideration of work and nonwork roles and career counselors should address the work-nonwork interface when helping clients to construct a career and manage career challenges (Whiston \& Cinamon, 2015). The whole-life career management framework offers a systematic approach based on an action regulation model for work-nonwork balance that can be a basis to derive career counseling interventions from a whole-life perspective. As such, it could serve as an important foundation for future career counseling practice and work-nonwork interventions and related research. 


\section{References}

Allen, T. D., Cho, E., \& Meier, L. L. (2014). Work-family boundary dynamics. Annual Review of Organizational Psychology and Organizational Behavior, 1(1), 99-121. doi:10.1146/annurev-orgpsych-031413-091330

Campbell, C., \& Ungar, M. (2004). Constructing a Life That Works: Part 2, An Approach to Practice. Career Development Quarterly, 53(1), 28-40.

Cinamon, R. G. (2014). The synergy project: A group career counseling intervention to enhance work-family management. In P. J. Hartung, M. L. Savickas, \& W. B. Walsh (Eds.), APA Handbook of Career Intervention (Vol. Volume 2: Applications pp. 413425). Washington, DC: American Psychological Association.

Clark, S. L., \& Freitas, A. L. (2013). Construing action abstractly and perceiving consonance among goal pursuits: Implications for activity substitutability and the accessibility of activity-goal links. Motivation and Emotion, 37(3), 537-549. doi:10.1007/s11031-0129334-1

DiRenzo, M. S., Greenhaus, J. H., \& Weer, C. H. (2015). Relationship between protean career orientation and work-life balance: A resource perspective. Journal of Organizational Behavior, 36(4), 538-560. doi:10.1002/job.1996

Edwards, J. R., \& Rothbard, N. P. (2000). Mechanisms linking work and family: Clarifying the relationship between work and family constructs. The Academy of Management Review, 25(1), 178-199. doi:10.2307/259269

Freitas, A. L., Clark, S. L., Kim, J. Y., \& Levy, S. R. (2009). Action-construal levels and perceived conflict among ongoing goals: Implications for positive affect. Journal of Research in Personality, 43(5), 938-941. doi:10.1016/j.jrp.2009.05.006

Frese, M., \& Zapf, D. (1994). Action as the core of work psychology: A German approach. In H. C. Triandis, M. D. Dunnette, \& L. Hough (Eds.), Handbook of industrial and organizational psychology (Vol. 4, pp. 271-340). Palo Alto, CA: Consulting Psychologists Press.

Greenhaus, J. H., \& Kossek, E. E. (2014). The contemporary career: A work-home perspective. Annual Review of Organizational Psychology and Organizational Behavior, 1(1), 361-388. doi:10.1146/annurev-orgpsych-031413-091324

Greer, T. W., \& Egan, T. M. (2012). Inspecting the hierarchy of life roles: A systematic review of role salience literature. Human Resource Development Review, 11(4), 463-499. doi:10.1177/1534484312445322

Hall, D. T., Yip, J., \& Doiron, K. (2018). Protean careers at work: Self-direction and values orientation in psychological success. Annual Review of Organizational Psychology and Organizational Behavior, 5(1), 129-156. doi:10.1146/annurev-orgpsych-032117104631 
Hammer, L. B., Kossek, E. E., Anger, W. K., Bodner, T., \& Zimmerman, K. L. (2011). Clarifying work-family intervention processes: The roles of work-family conflict and family-supportive supervisor behaviors. Journal of Applied Psychology, 96(1), 134150. doi:10.1037/a0020927

Hansen, L. S. (2001). Integrating Work, Family, and Community Through Holistic Life Planning. Career Development Quarterly, 49(3), 261-274.

Hansen, L. S. (2011). integrative life planning: a holistic approach. Journal of Employment Counseling, 48(4), 167-169. doi:10.1002/j.2161-1920.2011.tb01105.x

Harkin, B., Webb, T. L., Chang, B. P. I., Prestwich, A., Conner, M., Kellar, I., . . Sheeran, P. (2016). Does monitoring goal progress promote goal attainment? A meta-analysis of the experimental evidence. Psychological Bulletin, 142(2), 198-229. doi:10.1037/bul0000025

Heckhausen, J., Wrosch, C., \& Schulz, R. (2010). A motivational theory of life-span development. Psychological Review, 117(1), 32-60.

Hirschi, A., Shockley, K. M., \& Zacher, H. (2019). Achieving work-family balance: An action regulation model. Academy of Management Review, 44(1), 150-171. doi:10.5465/amr.2016.0409

Johnson, R. E., Chang, C. H., \& Lord, R. G. (2006). Moving from cognition to behavior: What the research says. Psychological Bulletin, 132(3), 381-415. doi:10.1037/00332909.132.3.381

Kiburz, K. M., Allen, T. D., \& French, K. A. (2017). Work-family conflict and mindfulness: Investigating the effectiveness of a brief training intervention. Journal of Organizational Behavior, 38(7), 1016-1037. doi:10.1002/job.2181

Kossek, E. E., Hammer, L. B., Kelly, E. L., \& Moen, P. (2014). Designing work, family \& health organizational change initiatives. Organizational Dynamics, 43(1), 53-63. doi:10.1016/j.orgdyn.2013.10.007

Kossek, E. E., Ruderman, M. N., Braddy, P. W., \& Hannum, K. M. (2012). Work-nonwork boundary management profiles: A person-centered approach. Journal of Vocational Behavior, 81(1), 112-128. doi:10.1016/j.jvb.2012.04.003

Kruglanski, A. W., Köpetz, C., Bélanger, J. J., Chun, W. Y., Orehek, E., \& Fishbach, A. (2013). Features of Multifinality. Personality and Social Psychology Review, 17(1), 22-39. doi:10.1177/1088868312453087

Kruglanski, A. W., Shah, J. Y., Fishbach, A., Friedman, R., Woo Young, C., \& SleethKeppler, D. (2002). A theory of goal systems. Advances in Experimental Social Psychology, 34, 331-378.

Krumboltz, J. D. (2009). The Happenstance Learning Theory. Journal of Career Assessment, 17(2), 135-154. doi:10.1177/1069072708328861 
Latham, G. P., \& Locke, E. A. (2006). Enhancing the Benefits and Overcoming the Pitfalls of Goal Setting. Organizational Dynamics, 35(4), 332-340.

doi:10.1016/j.orgdyn.2006.08.008

Lent, R. W. (2013). Career-life preparedness: Revisiting career planning and adjustment in the new workplace. The Career Development Quarterly, 61(1), 2-14. doi:10.1002/j.2161-0045.2013.00031.x

Lent, R. W., \& Brown, S. D. (2006). Integrating person and situation perspectives on work satisfaction: A social-cognitive view. Journal of Vocational Behavior, 69(2), 236-247.

Lent, R. W., \& Brown, S. D. (2013). Social cognitive model of career self-management: Toward a unifying view of adaptive career behavior across the life span. Journal of Counseling Psychology, 60(4), 557-568. doi:10.1037/a0033446

Lent, R. W., Brown, S. D., \& Hackett, G. (2000). Contextual supports and barriers to career choice: A social cognitive analysis. Journal of Counseling Psychology, 47(1), 36-49. doi:10.1037/0022-0167.47.1.36

Litano, M. L., \& Major, D. A. (2016). Facilitating a whole-life approach to career development:The role of organizational leadership. Journal of Career Development, 43(1), 52-65. doi:10.1177/0894845315569303

Locke, E. A., \& Latham, G. P. (2002). Building a practically useful theory of goal setting and task motivation: A 35-year odyssey. American Psychologist, 57(9), 705-717. doi:10.1037/0003-066X.57.9.705

Lord, R. G., Diefendorff, J. M., Schmidt, A. M., \& Hall, R. J. (2010). Self-regulation at work. Annual Review of Psychology, 61, 543-568. doi:10.1146/annurev.psych.093008.100314

Luthans, F., Avey, J. B., Avolio, B. J., Norman, S. M., \& Combs, G. M. (2006). Psychological capital development: Toward a micro-intervention. Journal of Organizational Behavior, 27(3), 387-393. doi:10.1002/job.373

Ramarajan, L. (2014). Past, present and future research on multiple identities: Toward an intrapersonal network approach. The Academy of Management Annals, 8(1), 589659. doi:10.1080/19416520.2014.912379

Savickas, M. L. (2012). Life design: A paradigm for career intervention in the 21st Century. Journal of Counseling and Development, 90(1), 13-19. doi:10.1111/j.15566676.2012.00002.x

Savickas, M. L. (2013). Career construction theory and practice. In S. D. Brown \& R. W. Lent (Eds.), Career development and counseling: Putting theory and research to work (2nd ed., pp. 42-70). Hoboken, NJ: Wiley. 
Slan-Jerusalim, R., \& Chen, C. P. (2009). Work-family conflict and career development theories: A search for helping strategies. Journal of Counseling \& Development, $87(4), 492-500$.

Super, D. E. (1957). The psychology of careers. New York: Harper \& Row.

Super, D. E. (1990). A life-span, life-space approach to career development. In D. Brown \& L. Brooks (Eds.), Career choice and development (2nd ed., pp. 197-262). San Francisco, CA: Jossey-Bass.

ten Brummelhuis, L. L., \& Bakker, A. B. (2012). A resource perspective on the work-home interface: The work-home resources model. American Psychologist, 67(7), 545-556. doi:10.1037/a0027974

Unsworth, K., Yeo, G., \& Beck, J. (2014). Multiple goals: A review and derivation of general principles. Journal of Organizational Behavior, 35(8), 1064-1078. doi:10.1002/job.1963

Vallacher, R. R., \& Wegner, D. M. (1987). What Do People Think Theyre Doing - Action Identification and Human-Behavior. Psychological Review, 94(1), 3-15. doi:Doi 10.1037//0033-295x.94.1.3

Vanhove, A. J., Herian, M. N., Perez, A. L. U., Harms, P. D., \& Lester, P. B. (2016). Can resilience be developed at work? A meta-analytic review of resilience-building programme effectiveness. Journal of Occupational and Organizational Psychology, 89(2), 278-307. doi:10.1111/joop.12123

Wayne, J. H., Butts, M. M., Casper, W. J., \& Allen, T. D. (2017). In search of balance: A conceptual and empirical integration of multiple meanings of work-family balance. Personnel Psychology, 70(1), 167-210. doi:10.1111/peps.12132

Whiston, S. C. (2008). Principles and applications of assessment in counseling. Belmont, CA: Brooks/Cole, Cengage Learning.

Whiston, S. C., Campbell, W. L., \& Maffini, C. S. (2012). Work-family balance: A counseling psychology perspective. In N. A. Fouad, J. A. Carter, \& L. M. Subich (Eds.), APA handbook of counseling psychology, Vol. 2: Practice, interventions, and applications (pp. 75-102). Washington, DC, US: American Psychological Association.

Whiston, S. C., \& Cinamon, R. G. (2015). The Work-Family Interface: Integrating Research and Career Counseling Practice. The Career Development Quarterly, 63(1), 44-56. doi:10.1002/j.2161-0045.2015.00094.x

Wrosch, C., Scheier, M. F., Miller, G. E., Schulz, R., \& Carver, C. S. (2003). Adaptive selfregulation of unattainable goals: Goal disengagement, goal reengagement, and subjective well-being. Personality and Social Psychology Bulletin, 29(12), 1494-1508. doi:10.1177/0146167203256921 
Zacher, H., \& Frese, M. (2018). Action regulation theory: Foundations, current knowledge, and future directions. In N. Anderson, D. S. Ones, C. Viswesvaran, \& H. K. Sinangil (Eds.), The SAGE Handbook of Industrial, Work, \& Organizational Psychology (2nd ed., Vol. 2, pp. 80-102). Thousand Oaks, CA: Sage.

Zacher, H., Kooij, D. T. A. M., \& Beier, M. E. (2017). Active aging at work: Contributing factors and implications for organizations. Organizational Dynamics.

doi:10.1016/j.orgdyn.2017.08.001 
Table 1

Phases, Core Aims, and Principal Tasks of the Whole-Life Career Counseling Intervention Framework

\begin{tabular}{|c|c|c|}
\hline Phase & $\begin{array}{l}\text { Core aims } \\
\text { To assist clients to: }\end{array}$ & Principal tasks \\
\hline $\begin{array}{l}\text { Stage 1: Clarifying work and } \\
\text { nonwork goals and their } \\
\text { linkages }\end{array}$ & $\begin{array}{l}\text { - understand current most important life roles } \\
\text { - understand what they aim to achieve in the work } \\
\text { role and in the most important nonwork roles } \\
\text { - understand how work and nonwork goals can } \\
\text { facilitate or inhibit each other }\end{array}$ & $\begin{array}{l}\text { - List life roles and assess their importance } \\
\text { - Identify work and nonwork goals by reflecting on } \\
\text { centrally valued aims in each life role } \\
\text { - Inquire about expectations of important others in } \\
\text { work and nonwork roles } \\
\text { - Clarify role boundaries and boundary preferences } \\
\text { - Identify goal conflicts and goal facilitation across } \\
\text { life roles }\end{array}$ \\
\hline $\begin{array}{l}\text { Stage 2: Mapping resources } \\
\text { and barriers related to work } \\
\text { and nonwork goals }\end{array}$ & $\begin{array}{l}\text { - understand available personal and contextual } \\
\text { resources that help attaining personal work and } \\
\text { nonwork goals } \\
\text { • identify personal and contextual resources to attain } \\
\text { work and nonwork goals } \\
\text {-identify personal and contextual barriers that inhibit } \\
\text { attaining work and nonwork goals }\end{array}$ & $\begin{array}{l}\text {-Identify personal characteristics and } \\
\text { competencies that help to attain work and } \\
\text { nonwork goals } \\
\text {-Identify family, organizational, and societal factors } \\
\text { that help to attain work and nonwork goals } \\
\text { - Identify personal and contextual barriers and } \\
\text { assess their impact on work and nonwork goal } \\
\text { attainment }\end{array}$ \\
\hline $\begin{array}{l}\text { Stage 3: Developing action } \\
\text { strategies to jointly attain } \\
\text { work and nonwork goals }\end{array}$ & $\begin{array}{l}\text {-identify specific actions steps to attain work and } \\
\text { nonwork goals } \\
\text { • develop action strategies how to use and increase }\end{array}$ & $\begin{array}{l}\text {-Break down longer-term abstract goals into } \\
\text { shorter-term, specific sub-goals } \\
\text {-Identify alternative ways to attain work and }\end{array}$ \\
\hline
\end{tabular}




\begin{tabular}{|c|c|c|}
\hline & $\begin{array}{l}\text { resources } \\
\text {-develop action strategies how to deal with barriers } \\
\text { - prioritize work and nonwork goals if needed } \\
\text { - change work and nonwork goals and develop new } \\
\text { goals if needed }\end{array}$ & $\begin{array}{l}\text { nonwork goals } \\
\text { - Reflect on strategies to address barriers } \\
\text {-Identify work and nonwork goals that can } \\
\text { temporarily be postponed } \\
\text { - Formulate new work and nonwork goals in } \\
\text { accordance with resources and barriers }\end{array}$ \\
\hline $\begin{array}{l}\text { Stage 4: Monitoring goal } \\
\text { progress and adapting }\end{array}$ & $\begin{array}{l}\text { - monitor changes in role expectations, resources, } \\
\text { and barriers } \\
\text { • monitor if actions correspond to plans } \\
\text { - monitor if actions have desired effects } \\
\text { •establish how to react to feedback } \\
\text { - evaluate feedback and adapt goals, plans, and } \\
\text { behaviors based on feedback if necessary }\end{array}$ & $\begin{array}{l}\text { - Specify when and how to monitor if actions } \\
\text { correspond to plans } \\
\text {-Specify when and how to evaluate goal progress } \\
\text {-Evaluate how to change action plans based on } \\
\text { feedback of goal attainment and progress } \\
\text {-Evaluate if role expectations have changed and } \\
\text { necessitate adapting work and nonwork goals }\end{array}$ \\
\hline
\end{tabular}




\section{Key process and components of whole-life career management interventions}

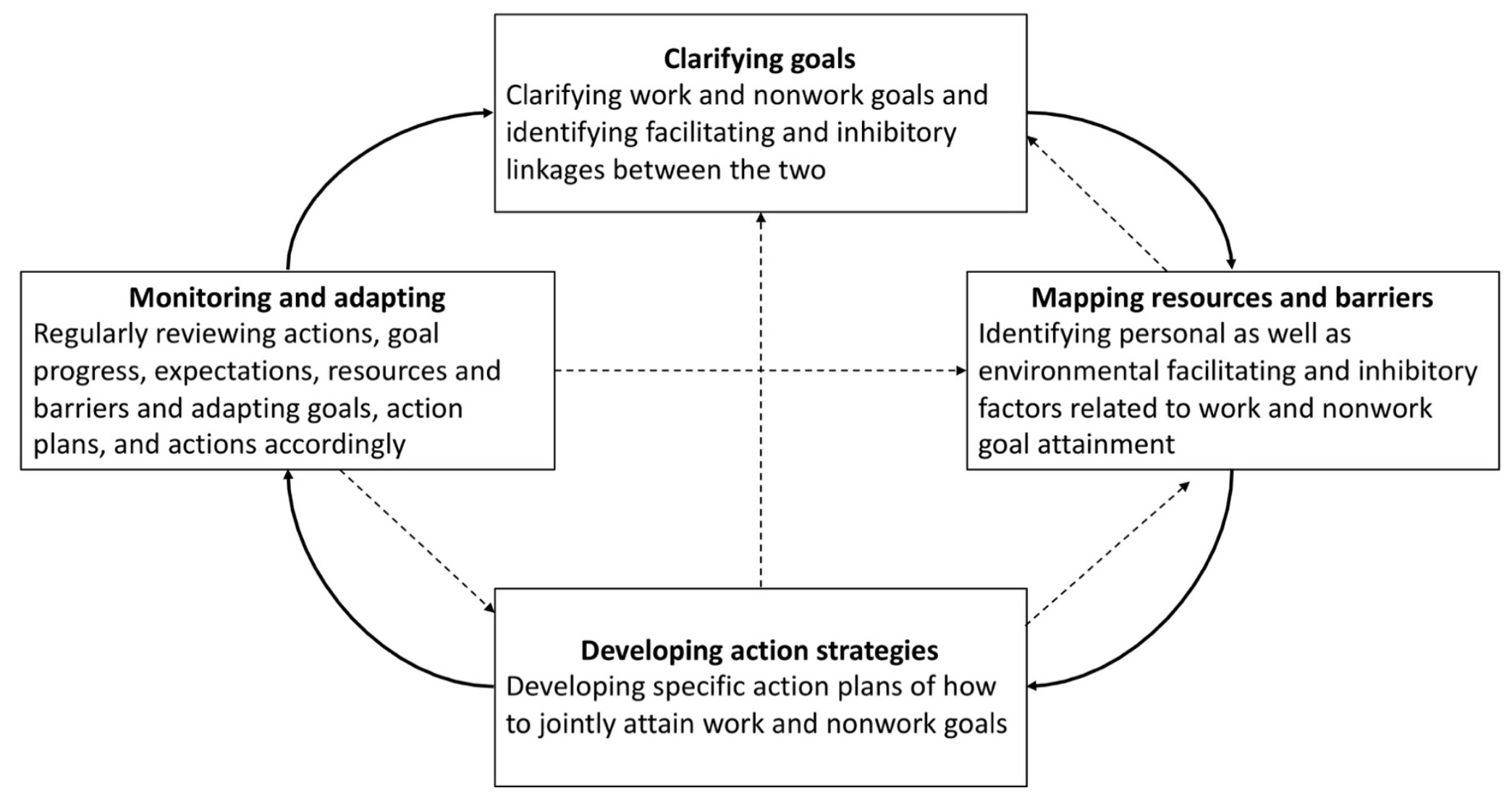

Figure 1. The proposed whole-life career management intervention framework. Dashed arrows indicate possible feedback loops. 